\title{
Anti-inflammatory Compounds from the Leaves of Ailanthus altissima
}

\author{
Meihua JiN ${ }^{1}$, KiHwan BAE ${ }^{2, *}$, Hyeun Wook HANG $^{1}$, and Jong Keun SoN ${ }^{1, *}$ \\ ${ }^{1}$ College of Pharmacy, Yeungnam University, Gyeongsan $712-749,{ }^{2}$ College of Pharmacy, \\ Chungnam National University, Daejeon 305-764, Republic of Korea
}

(Received January 6, 2009; Revised January 16, 2009; Accepted January 21, 2009)

\begin{abstract}
In our ongoing search for biological components from the Korea endemic plants, the MeOH extract of Ailanthus altissima leaves (Simaroubaceae) showed cyclooxygenase-2 (COX-2) and 5-lipoxygenase (5-LOX) dual inhibitory activity by assessing their effects on the production of prostaglandin $\mathrm{D}_{2}$ $\left(\mathrm{PGD}_{2}\right)$ and leukotriene $\mathrm{C}_{4}\left(\mathrm{LTC}_{4}\right)$ in mouse bone marrow-derived mast cells (BMMCs). In further study, eight compounds, squalene (1), $\beta$-sitosterol (2), scopoletin (3), quercetin (4), luteolin (5), astragalin (6), scopolin (7), and daucosterol (8) were isolated, the chemical structures were elucidated on the basis of physicochemical and spectroscopic data and by comparison with those of published literatures. Among the compounds, 2, 4, and 5 strongly inhibited both the COX-2-dependent $\mathrm{PGD}_{2}$ generation with $\mathrm{IC}_{50}$ values of 2.6, 7.3 and $2.5 \mu \mathrm{M}$, respectively and the generation of $\mathrm{LTC}_{4}$ in the 5-LOX dependent phase with $\mathrm{IC}_{50}$ values of $2.0,5.1$ and $1.8 \mu \mathrm{M}$, respectively, which suggest that the anti-inflammatory activity of $A$. altissima might occur in part via the inhibition of both $\mathrm{PGD}_{2}$ and $\mathrm{LTC}_{4}$ generation by 2, 4 and 5 .
\end{abstract}

Keywords: Ailanthus altissima, Simaroubaceae, Chemical constituents, Cyclooxygenase-2, 5-Lipoxygenase, Anti-inflammatory activity

\section{INTRODUCTION}

Ailanthus altissima (A. altissima), commonly known as the 'tree of heaven', is used in traditional medicine in many parts of Asia including China to treat cold and gastric diseases. Extract of $A$. altissima, has demonstrated anti-proliferative and central nerve depressant activities (O'Neill et al., 1986; Crespi Perellino et al., 1988; De Feo et al., 2005). Among the bioactive compounds isolated from A. altissima, quassinoids have various biological activities such as anti-tumor, anti-viral, anti-tuberculosis and anti-plasmodial activities (Kubota et al., 1997; Ohno et al., 1997; Rahman et al., 1997; Tamura et al., 2002; Okunade et al., 2003; Tamura et al., 2003).

Eicosanoids are inflammatory mediators that are biosynthesized in many cell types by cyclooxygenases (COX) and lipoxygenases (LOX). They are strongly associated with inflammatory disorders, acute as well as chronic inflammation. The inhibition of eicosanoid production is

\section{${ }^{*}$ Corresponding author}

Tel: +82-53-810-2817 (JK Son), +82-42-821-5925 (KH Bae)

Fax: +82-53-810-4654 (JK Son), +82-42-822-5343 (KH Bae)

E-mail: jkson@yu.ac.kr (JK Son), baekh@cuvic.cnu.ac.kr (KH Bae) one of the important therapeutic strategies in various inflammatory diseases. Among the eicosanoid generating enzymes, COX-2 was found to be essential for the production of PGs in inflammatory sites (Seibert et al., 1994). LTs produced by 5 -LOX also participate in the pathogenesis of bronchial asthma (Arm, 2004). Therefore, the dual inhibitors of COX-2/5-LOX are believed to be the ideal treatment for allergic diseases and asthma as nonsteroidal anti-inflammatory drugs (NSAIDs) (Fiorucci et al., 2001).

Recently, we reported that anti-inflammatory activity of ethanol extracts of $A$. altissima through the COX-2 and 5-LOX assays (Jin et al., 2006). However, the bioactive constituents of the leaves of $A$. altissima have not yet been characterized. This paper describes the isolation compounds from A. altissima and evaluation of COX-2 and 5-LOX inhibitory activities of the isolates.

\section{MATERIALS AND METHODS}

\section{Plant material}

The leaves of $A$. altissima were collected in August 2005 at Herbal Garden of Chungnam National University, Daejeon and identified by one of the authors (K. Bae). A voucher specimen (CNU 1539) was deposited at the her- 
barium in the College of Pharmacy, Chungnam National University.

\section{Instruments and reagents}

The melting points were measured using an Electrothermal melting point apparatus and are uncorrected. The UV and IR spectra were recorded with a Beckman Du-650 UV-VIS recording spectrophotometer and a Jasco Report100 infrared spectrometer, respectively. The NMR spectra were recorded on a JEOL 300 FT-NMR spectrometer $\left({ }^{1} \mathrm{H}\right.$, $300 \mathrm{MHz},{ }^{13} \mathrm{C}, 75 \mathrm{MHz}$ ) with tetramethylsilane (TMS) as the internal standard. The EIMS data were obtained using a Hewlett-Packard 5989B spectrometer. Column chromatography was carried out with silica gel (Kieselgel 60, 70-230 mesh and 230-400 mesh, Merck). Thin layer chromatography (TLC) was performed on pre-coated silica gel $60 \mathrm{~F}_{254}(0.25 \mathrm{~mm}$, Merck), visualized with a UV lamp, and also by spraying with a $10 \% \mathrm{H}_{2} \mathrm{SO}_{4}$ solution and heating.

\section{Extraction and isolation}

The leaves of $A$. altissima $(2.6 \mathrm{~kg})$ were extracted with $\mathrm{MeOH}$ twice under reflux for $3 \mathrm{~h}$, then filtered and concentrated to yield the $\mathrm{MeOH}$ extract $(220 \mathrm{~g})$. The $\mathrm{MeOH}$ extract was suspended in $\mathrm{H}_{2} \mathrm{O}$ and extracted successively with $\mathrm{n}$-hexane, EtOAc and then $\mathrm{n}-\mathrm{BuOH}$ to give $\mathrm{n}$-hexane fraction (62 g), EtOAc fraction (48 g), n-BuOH fraction (50 g) and water residue, respectively. The $n$-hexane fraction was subjected to column chromatography with silica gel and eluted using a stepwise gradient of n-hexane and EtOAc $(70: 1 \rightarrow 1: 1)$ to afford 3 subfractions $(\mathrm{H} 1-\mathrm{H} 3)$. Fractions $\mathrm{H} 2$ was chromatographed on a silica gel column using n-hexane-EtOAc (30:1) to give compounds 1 (15 $\mathrm{mg}$ ), and 2 (30 $\mathrm{mg}$ ).

The EtOAc fraction was applied to silica gel column and eluted with increasing polarity of n-hexane-acetone mixtures $(10: 1 \rightarrow 1: 1)$, to yield 5 subfrations (E1-E5). Fractions E2 was further purified over a silica gel column, with n-hexane-EtOAc (10:1) as the solvent system, resulting in compound 3 (65 mg). Fraction E3 was further purified by silica gel column chromatography with hexane-acetone $(6: 1)$ to afford compound 4 (15 mg), 5 (12 mg) and 6 (9 mg). Compound $7(20 \mathrm{mg})$ were obtained from subfraction E4 by MPLC system [ODS column $(11 \mathrm{~mm} \times 300 \mathrm{~mm}$, Yamazen), $\mathrm{MeOH}-\mathrm{H}_{2} \mathrm{O}$ (2:1), flow rate: $2 \mathrm{ml} / \mathrm{min}$, UV 254 $\mathrm{nm}$ ]. The $\mathrm{n}-\mathrm{BuOH}$ fraction was subjected to $\mathrm{LH} 20$ column chromatography using $\mathrm{MeOH}-\mathrm{H}_{2} \mathrm{O}$ gradient $(1: 100 \rightarrow$ $100: 1)$ to give 5 subfractions. Compound 8 (40 mg) was obtained from subfraction 4 by using MPLC system [ODS column (11 mm×300 mm, Yamazen), $\mathrm{MeOH}-\mathrm{H}_{2} \mathrm{O}$ (2:1), flow rate: $2 \mathrm{ml} / \mathrm{min}$, UV $254 \mathrm{~nm}$ ].

\section{Squalene (1)}

Colorless oil; UV $\lambda_{\max }(\mathrm{MeOH}) \mathrm{nm}(\log \varepsilon)$ : 220 (3.7); FABMS m/z: $433[\mathrm{M}+\mathrm{Na}]^{+} ;{ }^{1} \mathrm{H}-\mathrm{NMR}\left(300 \mathrm{MHz}, \mathrm{CDCl}_{3}\right) \delta$ : $5.16(6 \mathrm{H}, \mathrm{m}, \mathrm{H}-4,9,14), 2.10\left(2 \mathrm{H}, \mathrm{m}, \mathrm{CH}_{2}\right), 1.70(6 \mathrm{H}, \mathrm{s}$, $\mathrm{H}-2), 1.62(18 \mathrm{H}, \mathrm{s}, \mathrm{H}-1,8,13) .{ }^{13} \mathrm{C}-\mathrm{NMR}\left(75 \mathrm{MHz} \mathrm{CDCl}_{3}\right)$

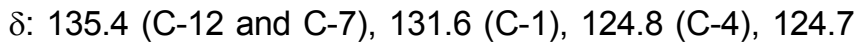
(C-14 and C-9), 40.1 (C-6 and C-11), 28.6 (C-15), 27.1 (C-5 and C-10), 26.0 (C-1), 18.0 (C-3), 16.4 (C-8 and C13).

\section{$\beta$-sitosterol (2)}

Colorless needle; mp $140-141^{\circ} \mathrm{C}$; IR $v_{\max }(\mathrm{KBr}) \mathrm{cm}^{-1}$ : $3320(\mathrm{OH}), 1642(\mathrm{C}=\mathrm{C}), 1050$ (C-O); ${ }^{1} \mathrm{H}-\mathrm{NMR}(300 \mathrm{MHz}$, $\left.\mathrm{CDCl}_{3}\right) \delta: 5.36(1 \mathrm{H}, \mathrm{d}, \mathrm{J}=5.4 \mathrm{~Hz}, \mathrm{H}-6), 3.52(1 \mathrm{H}, \mathrm{m}, \mathrm{H}-3)$, $1.02(3 \mathrm{H}, \mathrm{s}, \mathrm{H}-19), 0.94(3 \mathrm{H}, \mathrm{d}, \mathrm{J}=6.6 \mathrm{~Hz}, \mathrm{H}-21), 0.87(3 \mathrm{H}$, d, J=6.9 Hz, H-26), $0.84(3 \mathrm{H}, \mathrm{t}, \mathrm{J}=6.4 \mathrm{~Hz}, \mathrm{H}-29), 0.79(3 \mathrm{H}$, d, J=6.8 Hz, H-27), 0.70 (3H, s, H-18). ${ }^{13} \mathrm{C}-\mathrm{NMR}(75 \mathrm{MHz}$, $\mathrm{CDCl}_{3}$ ) $\delta: 141.2$ (C-5), 122.1 (C-6), 72.1 (C-3), 57.2 (C-14), 56.5 (C-17), 50.6 (C-9), 46.3 (C-24), 42.7 (C-13 and C-4), 40.2 (C-12), 37.7 (C-1), 36.9 (C-10), 36.3 (C-20), 34.4 (C-22), 32.3 (C-8) 32.0 (C-2 and C-7), 29.6 (C-27), 28.6 (C-16), 26.5 (C-23), 24.7 (C-15), 23.5 (C-25), 21.5 (C-11), 20.2 (C-19), 19.8 (C-29), 19.5 (C-28), 19.1 (C-21), 12.4 (C-26), 12.3 (C-18).

\section{Scopoletin (3)}

Yellow crystal; mp $202-204^{\circ} \mathrm{C}$; UV $\lambda_{\max }(\mathrm{MeOH}) \mathrm{nm}(\mathrm{log}$ ع): 210 (4.3), 300 (3.0), 338 (3.5), 350 (3.1), 352 (3.2), 358 (3.7), 366 (3.4); IR $v_{\max }(\mathrm{KBr}) \mathrm{cm}^{-1}: 3340(\mathrm{OH}), 3106$, 3031, 2990, 1710 (pyrone ring), $1600(\mathrm{C}=\mathrm{C}) ;{ }^{1} \mathrm{H}-\mathrm{NMR}(300$ MHz, DMSO-d 6 ) $\delta: 10.25(1 \mathrm{H}, \mathrm{s}, \mathrm{OH}), 7.90(1 \mathrm{H}, \mathrm{d}, \mathrm{J}=9.3$ $\mathrm{Hz}, \mathrm{H}-4), 7.21(1 \mathrm{H}, \mathrm{s}, \mathrm{H}-5), 6.78(1 \mathrm{H}, \mathrm{s}, \mathrm{H}-8), 6.21(1 \mathrm{H}, \mathrm{d}$, $\mathrm{J}=9.3 \mathrm{~Hz}, \mathrm{H}-3), 3.82\left(3 \mathrm{H}, \mathrm{s}, \mathrm{OCH}_{3}\right) .{ }^{13} \mathrm{C}-\mathrm{NMR}(75 \mathrm{MHz}$, DMSO-d 6 ) $\delta: 161.5$ (C-2), 152.0 (C-9), 150.3 (C-7), 146.1 (C-6), 145.3 (C-4), 112.5 (C-3), 111.4 (C-10), 110.5 (C-5), $103.6(\mathrm{C}-8), 56.9\left(\mathrm{OCH}_{3}\right)$.

\section{Quercetin (4)}

Yellow powder; negative ES-MS m/z: $301[\mathrm{M}-\mathrm{H}]-;{ }^{1} \mathrm{H}-$ NMR (300 MHz, DMSO-d 6 ) $\delta: 12.54(1 \mathrm{H}, \mathrm{s}, \mathrm{OH}-5), 9.39$ (3H, br, OH-3), $7.68\left(1 \mathrm{H}, \mathrm{dd}, \mathrm{J}=2.2,8.5 \mathrm{~Hz}, \mathrm{H}-2{ }^{\prime}\right), 7.54(1 \mathrm{H}$, dd, J=2.2 Hz, H-6'), $6.88\left(1 \mathrm{H}, \mathrm{d}, \mathrm{J}=8.5 \mathrm{~Hz}, \mathrm{H}-3^{\prime}\right), 6.40(1 \mathrm{H}$, $\mathrm{d}, \mathrm{J}=2.0 \mathrm{~Hz}, \mathrm{H}-8), 6.19(1 \mathrm{H}, \mathrm{d}, \mathrm{J}=2.0 \mathrm{~Hz}, \mathrm{H}-6) .{ }^{13} \mathrm{C}-\mathrm{NMR}$ (75 MHz, DMSO-d 6 ) $\delta: 160.7$ (C-2), 135.7 (C-3), 175.8 (C-4), 163.9 (C-5), 98.2 (C-6), 167.7 (C-7), 93.3 (C-8), 147.5 (C-9), 102.7 (C-10), 120.1 (C-1'), 115.0 (C-2'), 125.0 (C-3'), 146.8 (C-4'), 142.0 (C-5'), 121.5 (C-6').

\section{Luteolin (5)}

Yellow powder; positive FAB-MS m/z: $287.1[\mathrm{M}+\mathrm{H}]^{+}$; 
${ }^{1} \mathrm{H}-\mathrm{NMR}\left(300 \mathrm{MHz}, \mathrm{DMSO}-\mathrm{d}_{6}\right) \delta: 6.64(1 \mathrm{H}, \mathrm{s}, \mathrm{H}-3), 6.42$ $(1 \mathrm{H}, \mathrm{dd}, \mathrm{J}=2.0 \mathrm{~Hz}, \mathrm{H}-8), 6.16(1 \mathrm{H}, \mathrm{d}, \mathrm{J}=2.0 \mathrm{~Hz}, \mathrm{H}-6), 7.37$ $\left(1 \mathrm{H}, \mathrm{d}, \mathrm{J}=2.0,7.8 \mathrm{~Hz}, \mathrm{H}-2^{\prime}\right), 6.87\left(1 \mathrm{H}, \mathrm{d}, \mathrm{J}=8.0 \mathrm{~Hz}, \mathrm{H}-3^{\prime}\right)$, $7.40\left(1 \mathrm{H}, \mathrm{d}, \mathrm{J}=2.0 \mathrm{~Hz}, \mathrm{H}-6^{\prime}\right) .{ }^{13} \mathrm{C}-\mathrm{NMR}(75 \mathrm{MHz}$, DMSO$\left.\mathrm{d}_{6}\right) \delta$ : 164.5 (C-2), 103.4 (C-3), 172.2 (C-4), 162.1 (C-5), 99.5 (C-6), 165.0 (C-7), 94.5 (C-8), 158.0 (C-9), 104.2 (C10), 121.9 (C-1'), 113.9 (C-2'), 146.4 (C-3'), 150.6 (C-4'), 138.6 (C-5'), $119.6\left(\mathrm{C}-6^{\prime}\right)$.

\section{Astragalin (6)}

Yellow powder; positive FAB-MS m/z: $453.1[\mathrm{M}+\mathrm{H}]^{+}$; ${ }^{1} \mathrm{H}-\mathrm{NMR}\left(300 \mathrm{MHz}, \mathrm{DMSO}-\mathrm{d}_{6}\right) \delta$ : 3.08-3.66 $(\mathrm{m}$, sugar-H), 5.45 (d, J=7.2 Hz, H-1"), 6.19 (d, J=1.9 Hz, H-6), 6.42 (d, J $=1.8 \mathrm{~Hz}, \mathrm{H}-8), 6.88$ (d, J=6.8 Hz, H-3', 5'), 8.04 (d, J=6.9 $\left.\mathrm{Hz}, \mathrm{H}-2^{\prime}, 6^{\prime}\right), 12.60$ (s, OH-5). ${ }^{13} \mathrm{C}-\mathrm{NMR}(75 \mathrm{MHz}$, DMSO$\left.\mathrm{d}_{6}\right) \delta: 156.1$ (C-2), 133.1 (C-3), 177.3 (C-4), 161.1 (C-5), 98.7 (C-6), 164.5 (C-7), 93.6 (C-8), 156.4 (C-9), 103.8 (C-10), 120.8 (C-1'), 130.8 (C-2', 6'), 115.0 (C-3', 5'), 159.9 (C-4'), 100.8 (C-1"), 74.1 (C-2"), 77.4 (C-3"), 69.8 (C-4"), 76.3 (C-5"), 60.8 (C-6").

\section{Scopolin (7)}

White powder; mp $217-219^{\circ} \mathrm{C}$; UV $\lambda_{\max }(\mathrm{MeOH}) \mathrm{nm}$ (log ع): 205 (4.9), 220 (4.2), 310 (4.3), 350 (4.9); IR $v_{\max }(\mathrm{KBr})$ $\mathrm{cm}^{-1}$ : $3440(\mathrm{OH}), 1700$ (-pyrone ring), $1610(\mathrm{C}=\mathrm{C}), 1280$, 1080 (C-O); FAB-MS m/z: $377[\mathrm{M}+\mathrm{Na}]^{+}$and $355[\mathrm{M}+\mathrm{H}]^{+}$; ${ }^{1} \mathrm{H}-N M R\left(300 \mathrm{MHz}, \mathrm{DMSO}-\mathrm{d}_{6}\right) \delta: 7.97(1 \mathrm{H}, \mathrm{d}, \mathrm{J}=9.6 \mathrm{~Hz}, \mathrm{H}-$ 4), $7.30(1 \mathrm{H}, \mathrm{s}, \mathrm{H}-5), 7.16(1 \mathrm{H}, \mathrm{s}, \mathrm{H}-8), 6.33(1 \mathrm{H}, \mathrm{d}, \mathrm{J}=9.6$ $\mathrm{Hz}, \mathrm{H}-3), 5.09\left(1 \mathrm{H}, \mathrm{d}, \mathrm{J}=7.5 \mathrm{~Hz}, \mathrm{H}-1^{\prime}\right), 3.82\left(3 \mathrm{H}, \mathrm{s}, \mathrm{OCH}_{3}\right)$, $3.69\left(1 \mathrm{H}, \mathrm{dd}, \mathrm{J}=9.6,5.4 \mathrm{~Hz}, \mathrm{H}-6^{\prime}\right), 3.16-3.45(4 \mathrm{H}, \mathrm{m}$, $\left.\mathrm{H}-2^{\prime}, 3^{\prime}, 4^{\prime}, 5^{\prime}\right) .{ }^{13} \mathrm{C}-\mathrm{NMR}\left(75 \mathrm{MHz}, \mathrm{DMSO}-\mathrm{d}_{6}\right) \delta: 161.4(\mathrm{C}-2)$, 150.7 (C-9), 149.8 (C-7), 146.8 (C-6), 145.1 (C-4), 114.2 (C-3), 113.1 (C-10), 110.5 (C-5), 103.8 (C-8), 100.4 (C-1'), 77.9 (C-3'), 77.5 (C-5'), 73.9 (C-2'), 70.4 (C-4'), 61.5 (C-6'), $56.9\left(\mathrm{OCH}_{3}\right)$.

\section{Daucosterol (8)}

Colorless crystal; mp $280-282^{\circ} \mathrm{C}$; IR $v_{\max }(\mathrm{KBr}) \mathrm{cm}^{-1}$ : $3391(\mathrm{OH}), 2361,1635$ (C=C), 1107 (C-O). ${ }^{1} \mathrm{H}-\mathrm{NMR}$ (300 $\left.\mathrm{MHz}, \mathrm{CD}_{3} \mathrm{OD}\right)$ : $: 5.30(1 \mathrm{H}, \mathrm{d}, \mathrm{J}=5.4 \mathrm{~Hz}, \mathrm{H}-6), 4.83(1 \mathrm{H}, \mathrm{d}$, $\left.\mathrm{J}=7.5 \mathrm{~Hz}, \mathrm{H}-1^{\prime}\right), 4.38(1 \mathrm{H}, \mathrm{m}, \mathrm{H}-3), 0.96(3 \mathrm{H}, \mathrm{s}, \mathrm{H}-19), 0.90$ $(3 \mathrm{H}, \mathrm{d}, \mathrm{J}=6.3 \mathrm{~Hz}, \mathrm{H}-21), 0.80(3 \mathrm{H}, \mathrm{d}, \mathrm{J}=6.0 \mathrm{~Hz}, \mathrm{H}-26), 0.79$ $(3 \mathrm{H}, \mathrm{t}, \mathrm{J}=6.6 \mathrm{~Hz}, \mathrm{H}-29), 0.66(3 \mathrm{H}, \mathrm{s}, \mathrm{H}-18) .{ }^{13} \mathrm{C}-\mathrm{NMR}(75$ $\left.\mathrm{MHz}, \mathrm{CD}_{3} \mathrm{OD}\right) \delta$ : $141.3(\mathrm{C}-5), 122.0(\mathrm{C}-6), 101.7\left(\mathrm{C}-1^{\prime}\right)$, 77.8 (C-3'), 77.6 (C-3 and C-5'), 74.4 (C-2'), 71.0 (C-4'), 61.5 (C-6'), 57.0 (C-14), 56.5 (C-17), 50.5 (C-9), 46.0 (C-24), 42.7 (C-13 and C-4), 40.2 (C-12), 37.7 (C-1), 36.9 (C-10), 36.3 (C-20), 34.4 (C-22), 32.3 (C-8), 32.0 (C-2 and C-7), 29.6 (C-27), 28.6 (C-16), 26.5 (C-23), 24.7 (C-15), 23.5 (C-25), 21.4 (C-11), 20.2 (C-19), 20.0 (C-29), 19.8
(C-28), 19.5 (C-21), 12.7 (C-26), 12.7 (C-18).

\section{Preparation and activation of bone marrow-derived mast cells (BMMCs)}

Bone marrow cells from male Balb/cJ mice were cultured for up to 10 weeks in $50 \%$ enriched medium (RPMI 1640 containing $2 \mathrm{mM}$ L-glutamine, $0.1 \mathrm{mM}$ nonessential amino acids, antibiotics and $10 \%$ fetal calf serum) and $50 \%$ WEHI-3 cell conditioned medium as a source of IL-3. After 3 weeks more than $98 \%$ of the cells were found to be BMMCs when checked by the previously described procedure (Muarakami et al., 1994).

\section{Determination of prostaglandin $\mathrm{D}_{2}\left(\mathrm{PGD}_{2}\right)$}

In order to measure the inhibitory activity on COX-2 by samples, the cells were suspended in enriched medium at a cell density of $5 \times 10^{5}$ cells $/ \mathrm{ml}$ and preincubated with aspirin $(10 \mu \mathrm{g} / \mathrm{ml})$ for $2 \mathrm{~h}$ to irreversibly inactivate any preexisting COX-1. After washing, the BMMC were activated with c-kit ligand (KL, $100 \mathrm{ng} / \mathrm{ml}), \mathrm{IL}-10(100 \mathrm{U} / \mathrm{ml})$ and LPS $(100 \mathrm{ng} / \mathrm{ml})$ at $37^{\circ} \mathrm{C}$ for $8 \mathrm{~h}$ in the presence or absence of the samples previously dissolved in dimethylsulfoxide (DMSO). All reactions were quenched by centrifugation at $120 \mathrm{~g}$ at $4^{\circ} \mathrm{C}$ for $5 \mathrm{~min}$. The supernatant and cell pellets were frozen immediately in liquid $\mathrm{N}_{2}$ and stored at $-80^{\circ} \mathrm{C}$ until needed for further analysis. Concentrations of $\mathrm{PGD}_{2}$ in the supernatant were measured using $\mathrm{PGD}_{2}$ assay kit (Cayman Chemical, Ann Arbor, MI, USA) according to manufacturer's instruction. Under these conditions, the COX-2-dependent phases of $\mathrm{PGD}_{2}$ generation reached 1.6 $\mathrm{ng} / 10^{6}$ cells. The data is reported as the arithmetic mean of triplicate determinations.

\section{Determination of leukotriene $\mathrm{C}_{4}\left(\mathrm{LTC}_{4}\right)$}

The BMMCs suspended in enriched medium at a density of $1 \times 10^{6}$ cells $/ \mathrm{ml}$ were pretreated with the samples for $15 \mathrm{~min}$ at $37^{\circ} \mathrm{C}$ and stimulated with $\mathrm{KL}(\mathrm{KL} ; 100 \mathrm{ng} / \mathrm{ml})$. After 20 min stimulation, the supernatants were isolated and analyzed by EIA. The $\mathrm{LTC}_{4}$ level was determined using an enzyme immunoassay kit (Cayman Chemical, Ann Arbor, MI, USA) according to the manufacture's instructions. Under these conditions, the $\mathrm{LTC}_{4}$ reached up to 500 $\mathrm{pg} / 10^{6}$ cells. The data is reported as the arithmetic mean of triplicate determinations.

\section{RESULTS AND DISCUSSION}

During our search for biologically active compounds derived from the endemic species in Korea, the n-hexane and EtOAc fractions of the $\mathrm{MeOH}$ extract of the leaves of 
A. altissima were shown to possess COX-2 and 5-LOX dual inhibitory activities by assessing their effects on the production of the $\mathrm{PGD}_{2}$ and $\mathrm{LTC}_{4}$ in mouse bone marrow-derived mast cells (BMMCs) (Table I). Repeated chromatography resulted in the isolation of eight compounds (Fig. 1). Based on comparison of ${ }^{1} \mathrm{H}$ and ${ }^{13} \mathrm{C}-\mathrm{NMR}$ spectral data of these compounds with published data, the isolated compounds were identified as 1-8 (Pistelli et al., 1996; Thuong et al., 2005).

Murakami et al. reported that BMMCs exhibit biphasic $\mathrm{PGD}_{2}$ biosynthetic responses over time, as well as COX-1dependent immediate and COX-2-dependent delayed responses (Murakami et al., 1994). The immediate generation of $\mathrm{PGD}_{2}$ that occurs within $2 \mathrm{~h}$ of culturing is associated with the coupling of COX-1, while the delayed generation of $\mathrm{PGD}_{2}$, which occurs after several hours of cultur-

Table I. Inhibitory effect of $\mathrm{MeOH}$ extract and solvent fractions against COX-2 and 5-LOX

\begin{tabular}{lcc}
\hline $\begin{array}{c}\text { Extract and } \\
\text { fractions }\end{array}$ & $\begin{array}{c}\text { COX-2 inhibition (\%) } \\
(50 \mu \mathrm{g} / \mathrm{ml})\end{array}$ & $\begin{array}{c}\text { 5-LO inhibition (\%) } \\
(50 \mu \mathrm{g} / \mathrm{ml})\end{array}$ \\
\hline $\mathrm{MeOH}$ & 49.0 & 98.9 \\
$\mathrm{Hexane}$ & 57.4 & 99.8 \\
$\mathrm{EtOAc}$ & 53.3 & 96.7 \\
$\mathrm{BuOH}$ & 0 & 99.0 \\
$\mathrm{H}_{2} \mathrm{O}$ & 0 & 0 \\
\hline
\end{tabular}

ing (2-10 h), is associated with the de novo induction and function of COX-2 after the stimulation with particular cytokines and LPS combinations (Murakami et al., 1994). This cell model also appears to be suitable for assessing the effect of 5-LOX inhibitors, since the immediate generation of $\mathrm{LTC}_{4}$ elicited by the IgE-dependent or cytokine-initiated stimulus occurs in BMMCs through 5-LOX (Murakami et al., 1995). Therefore, the BMMC system is useful for screening selective COX-1/COX-2 or 5-LOX and COX-2/ 5 -LOX dual inhibitors from various sources (Moon et al., 1999; Lee et al., 2004; Son et al., 2005; Son et al., 2006).

The generation of $\mathrm{PGD}_{2}$ in the COX-2-dependent phase and the generation of $\mathrm{LTC}_{4}$ in the 5-LOX dependent phase were tested after the BMMCs were activated with a combination of KL, IL-10 and LPS in the presence or absence of each compound. As the results, 2, 4, and 5 strongly inhibited both the COX-2-dependent $\mathrm{PGD}_{2}$ generation with $\mathrm{IC}_{50}$ values of $2.6,7.3$ and $2.5 \mu \mathrm{M}$, respectively and the generation of $\mathrm{LTC}_{4}$ in the 5-LOX dependent phase with $\mathrm{IC}_{50}$ values of 2.0, 5.1 and $1.8 \mu \mathrm{M}$, respectively (Table II). In this experiments, NS398 (COX-2 selective inhibitor) and AA861 (5-LOX inhibitor) were used as positive control (Makino et al., 1986; Ouellet et al., 1995). Under the same conditions, NS398 and AA861 strongly inhibited $\mathrm{PGD}_{2}$ and $\mathrm{LTC}_{4}$ generation of bone marrow-derived mast cells (BMMC) in a concentration-dependent manner with an $\mathrm{IC}_{50}$ of $1.6 \times 10^{-4} \mu \mathrm{M}$ and $3.2 \times 10^{-2} \mu \mathrm{M}$, respectively.

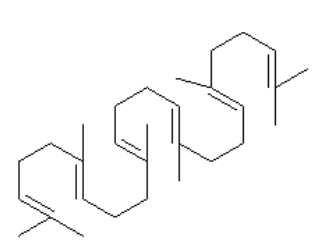

1<smiles>CCC(CC[C@@H](C)C1CCC2C3CC=C4C[C@@H](O)CC[C@]4(C)C3CC[C@]21C)C(C)C</smiles>

2<smiles>COc1cc2ccc(=O)oc2cc1O</smiles>

3<smiles></smiles>

4<smiles>COc1cc2ccc(=O)oc2cc1O</smiles>

7<smiles>O=c1cc(-c2ccc(O)c(O)c2)oc2cc(O)cc(O)c12</smiles>

5<smiles>COc1c(-c2ccc(O)c(O)c2)oc2cc(O)cc(O)c2c1=O</smiles>

6
Fig. 1. Chemical structures of isolated compounds (1-8). 
Table II. Inhibitory effect of isolated compounds against COX-2 and 5-LOX

\begin{tabular}{lcc}
\hline Compounds & $\begin{array}{c}\text { COX-2 inhibition } \\
\left(\mathrm{IC}_{50}, \mu \mathrm{M}\right)\end{array}$ & $\begin{array}{c}\text { 5-LOX inhibition } \\
\left(\mathrm{IC}_{50}, \mu \mathrm{M}\right)\end{array}$ \\
\hline 1 & $>100$ & 1.8 \\
2 & 2.6 & 2.0 \\
3 & 39.2 & 59.9 \\
4 & 7.3 & 5.1 \\
5 & 2.5 & 1.8 \\
6 & $>100$ & $>100$ \\
7 & $>100$ & $>100$ \\
8 & $>100$ & $>100$ \\
NS338 $^{\mathrm{a}}$ & $1.6 \times 10^{-4}$ & - \\
AA861 $^{\mathrm{a}}$ & - & $3.2 \times 10^{-2}$ \\
\hline
\end{tabular}

${ }^{\mathrm{a}}$ These compounds were used as positive controls.

These results suggest that the anti-inflammatory activity of $A$. altissima might occur via the inhibition of both $\mathrm{PGD}_{2}$ and $\mathrm{LTC}_{4}$ generation by 2,4 and 5 . It is interesting that glucosylation of 2, 4 and 5 to 8,7 and 6 , respectively, lead to complete loss of inhibitory activities in both $\mathrm{PGD}_{2}$ and $\mathrm{LTC}_{4}$ generation. COX-2 and 5-LOX inhibitory activity of luteolin and $\beta$-sitosterol isolated from the root of Dystaenia takeshimana, but no $\mathrm{IC}_{50}$ values of them, has been reported (Kim et al., 2006). COX-2 inhibitory activity, but no 5-LOX inhibitory activity of quercetin, has been reported (Raso et al., 2001). Further study will be needed to clarify the mechanisms for the action of these compounds isolated in this study.

\section{ACKNOWLEDGMENTS}

This work was supported by a Yeungnam University Research Grant in 2008.

\section{REFERENECES}

Arm, J. P. (2004). Leukotriene generation and clinical implications. Allergy Asthma. Proc. 25, 37.

Crespi Perellino, N., Guicciardi, A., Minghetti, A. and Speroni, E. (1988). Comparison of biological activity induced by Ailanthus altissima plant or cell cultures extracts. Pharmacol. Res. Commun. 5, 45.

De Feo, V. Martino, L. D., Santoro, A., Leone, A., Pizza, C., Franceschelli, S. and Pascale, M. (2005). Antiproliferative effects of tree-of-heaven (Ailanthus altissima Swingle). Phytother. Res. 19, 226.

Fiorucci, S., Meli, R., Bucci, M. and Cirino, G. (2001). Dual inhibitors of cyclooxygenase and 5-lipoxygenase. Biochem. Pharmacol. 62, 1433.

Jin, M. H., Yook, J. M., Lee, E. K., Lin, C. X., Quan, Z., Son, K. H., Bae, K. H., Kim, H. P., Kang, S. S. and Chang, H. W. (2006). Anti-inflammatory activity of Ailanthus altissima in ovalbumin-induced lung inflammation. Biol. Pharm. Bull. 29, 884.

Kim, J. S., Kim, J. C., Shim, S. H., Lee, E. J., Jin, W., Bae, K., Son, K. H., Kim, H. P., Kang, S. S. and Chang, H. W. (2006). Chemical constituents of the root of Dystaenia takeshimana and their anti-inflammatory activity. Arch. Pharm. Res. 29, 617.

Kubota, K., Fukamiya, N. Tokuda, H., Nishino, H., Tagahara, K., Lee, K. H. and Okano, M. (1997). Quassinoids as inhibitors of Epstein-Barr virus early antigen activation. Cancer Lett. 113, 165.

Lee, S. H., Son, M. J., Ju, H. K., Lin, C. X., Moon, T. C., Choi, H. G., Son, J. K. and Chang, H. W. (2004). Dual inhibition of cyclooxygenases-2 and 5-lipoxygenase by deoxypodophyllotoxin in mouse bone marrow-derived mast cells. Biol. Pharm. Bull. 27, 786 .

Makino, H., Ashida, Y., Saijo, T., Kuriki, H., Terao, S. and Maki, Y. (1986). Role of leukotrienes in rat reversed passive Arthus pleurisy and the effect of AA-861, a 5-lipoxygenase inhibitor. Int. Arch. Allergy Appl. Immunol. 79, 38.

Moon, T. C., Murakami, M., Kudo, I., Son, K. H., Kim, H. P., Kang, S. S. and Chang, H. W. (1999). A new class of COX-2 inhibitor, rutaecarpine from Evodia rutaecarpa. Inflamm. Res. 48, 621.

Murakami, M., Austen, K. F. and Arm, J. P. (1995). The immediate phase of c-kit ligand stimulation of mouse bone marrow-derived mast cells elicits rapid leukotriene $\mathrm{C}_{4}$ generation through posttranslational activation of cytosolic phospholipase $\mathrm{A}_{2}$ and 5-lipoxygenase. J. Exp. Med. 182, 197.

Murakami, M., Kambe, T., Shimbara, S. and Kudo, I. (1999). Functional coupling between various phospholipase $\mathrm{A}_{2} \mathrm{~S}$ and cyclooxygenases in immediate and delayed prostanoid biosynthetic pathways. J. Biol. Chem. 274, 3103.

Murakami, M., Matsumoto, R., Austen, K. F. and Arm, J. P. (1994). Prostaglandin endoperoxide synthase-1 and -2 couple to different transmembrane stimuli to generate prostaglandin D2 in mouse bone marrow-derived mast cells. J. Biol. Chem. 269, 22269.

O'Neill, M. J., Bray, D. H., Boardman, P., Phillipson, J. D. Warhurst, D. C., Peters, W. and Suffness, M. (1986). Plants as sources of antimalarial drugs: in vitro antimalarial activities of some quassinoids. Agents Chemother. 30, 101.

Ohno, N., Fukamiya, N., Okano, M., Tagahara, K. and Lee, K. H. (1997). Synthesis of cytotoxic fluorinated quassinoids. Bioorg. Med. Chem. 5, 1489

Okunade, A. L., Bikoff, R. E., Casper, S. J., Oksman, A. Goldber, D. E. and Lewis, W. H. (2003). Antiplasmodial activity of extracts and quassinoids isolated from seedlings of Ailanthus altissima (Simaroubaceae). Phytother. Res. 17, 675.

Pistelli, L., Bertoli, A., Bilia, A.R. and Morelli, I. (1996). Minor constituents from Bupleurum fruticosumroots. Phytochemistry 41, 1579.

Rahman, S., Fukamiya, N., Okano, M., Tagahara, K. and Lee, K. H. (1997). Anti-tuberculosis activity of quassinoids. Chem. Pharm. Bull. (Tokyo). 45, 1527.

Raso, G.M., Meli, R., Di Carlo, G. Pacilio, M. and Di Carlo, R. (2001). Inhibition of inducible nitric oxide synthase and cyclooxygenase-2 expression by flavonoids in macrophage J774A.1. Life Sci. 68, 921. 
Seibert, K., Zhang, Y., Leahy, K., Hauser, S., Masferrer, J., Perkins, W., Lee, L. and Isakson, P. (1994). Pharmacological and biochemical demonstration of the role of cyclooxygenase-2 in inflammation and pain. Proc. Natl. Acad. Sci. U. S. A., 91, 12013.

Son, J. K., Son, M. J., Lee, E. K., Moon, T. C., Son, K. H., Kim, C. H., Kim, H. P., Kang, S. S. and Chang, H. W. (2005). Ginkgetin, a Biflavone from Ginko biloba leaves, inhibits cyclooxygenases-2 and 5-lipoxygenase in mouse bone marrow-derived mast cells. Biol. Pharm. Bull. 28, 2181.

Son, M. J., Moon, T. C., Lee, E. K., Son, K. H., Kim, H. P., Kang, S. S., Son, J. K., Lee, S. H. and Chang, H. W. (2006). Naturally occurring biflavonoid, ochnaflavone, inhibits cyclooxygenases-2 and 5-lipoxygenase in mouse bone marrowderived mast cells. Arch. Pharm. Res. 29, 282.

Tamura, S., Fukamiya,N., Okano, M., Koyama, J., Koike, K.,
Tokuda, H., Aoi, W., Takayasu, J., Kuchide, M. and Nishino, H. (2003). Three new quassinoids, ailantinol E, F, and G, from Ailanthus altissima. Chem. Pharm. Bull. (Tokyo). 51, 385.

Tamura, S., Fukamiya, N., Okano, M., Tokuda, H., Aoi, W., Mukainaka, T., Nishino, H., Tagahara, K. and Koike, K. (2002). Cancer chemopreventive effect of quassinoid derivatives. Introduction of side chain to shinjulactone $C$ for enhancement of inhibitory effect on Epstein-Barr virus activation. Cancer Lett. 185, 47.

Thuong, P. T., Jin, W., Lee, J., Seong, R., Lee, Y. M., Seong, Y., Song, K. and Bae, K. (2005). Inhibitory effect on TNF-alphainduced IL-8 production in the HT29 cell of constituents from the leaf and stem of Weigelasubsessilis. Arch. Pharm. Res. 28, 1135. 